\title{
DISINFECTANT AND ANTIBIOTIC ACTIVITIES: A COMPARATIVE ANALYSIS IN BRAZILIAN HOSPITAL BACTERIAL ISOLATES
}

\author{
Márcia Aparecida Guimarães; Anita Tibana; Marly Paiva Nunes; Kátia Regina Netto dos Santos* \\ Departamento de Microbiologia Médica, Instituto de Microbiologia Professor Paulo de Góes, \\ Universidade Federal do Rio de Janeiro, Rio de Janeiro, RJ, Brazil.
}

Submitted: August 06, 1999; Returned to authors for corrections: April 24, 2000; Approved: June 26, 2000

\begin{abstract}
Nosocomial infections are an important cause of morbidity and mortality all over the world. It has been shown that appropriate environmental hygienic and disinfection practices can be very helpful to hospital infection control. The purpose of this study was to evaluate the bactericidal activity of some disinfectants against antibiotic-susceptible and antibiotic-resistant hospital bacterial isolates. The susceptibility of 27 clinical isolates to disinfectants and antibiotics was determined by the Association of Official Analytical Chemist's (AOAC) Use-Dilution method and by the Kirby-Bauer method, respectively. All strains tested were susceptible to sodium hypochlorite, glutaraldehyde and to the association quaternary ammonium formaldehyde - ethyl alcohol disinfectants. However, the susceptibility of strains to phenol and to one quaternary ammonium compound was variable. Among twenty-one antibiotic-multiresistant strains (methicillin-resistant staphylococci, Enterococcus spp, Pseudomonas aeruginosa, Klebsiella pneumoniae, Proteus mirabilis, Enterobacter cloacae, Serratia marcescens and Escherichia coli) eleven (52\%) and eight (38\%) strains were resistant to the quaternary ammonium and phenol compounds, respectively. Among six isolates that demonstrated susceptibility to antibiotics (staphylococci, Enterococcus spp, P. mirabilis, E. cloacae and E. coli) two strains (33\%) showed resistance to these disinfectants. The results demonstrated the lack of correlation between antibiotic-susceptibility and susceptibility to disinfectants in hospital strains.
\end{abstract}

Key words: disinfectant activity, antibiotic activity, hospital isolates

\section{INTRODUCTION}

There has been an interest in improving the sterilization and disinfection procedures to reduce the infection risk for hospitalized patients and healthcare workers (5). Disinfectantresistant bacterial strains have arisen as a result of the lack in standardization of some factors, such as criteria for use of chemicals agents, specifications in the labels of available products and scarcity of well-trained personnel (17).

The prevalence of antibiotic-resistant hospital bacteria have increased significantly in the world (2), including Brazil (17), and has become a serious public health problem. Methicillinresistant Staphylococcus aureus (MRSA), vancomycinresistant Enterococcus (VRE) and multiresistant
Gram-negative bacilli have been tested for susceptibility to disinfectants, with disagreeing results $(1,3,16,21,22)$. The widespread use of antiseptic and disinfectant products has prompted some speculation on the development of microbial resistance, in particular cross-resistance to antibiotics (13).

The selection, use and control of the effectiveness of the disinfectants have been emphasized, since environmental surfaces and medical and surgical instruments can serve as vehicles to infectious agents in susceptible hosts associated with the hospital setting (20). Considering the importance of the disinfection for the prevention of nosocomial infections, the aim of this study was to evaluate the bactericidal action of five disinfectants commonly used in hospitals against antibioticsusceptible and antibiotic-resistant clinical isolates.

\footnotetext{
* Corresponding author. Mailing address: Instituto de Microbiologia Prof. Paulo de Góes, UFRJ, Departamento de Microbiologia Médica, CCS, Bloco I, Cidade Universitária, CEP: 21941-590, Rio de Janeiro, RJ, Brazil. Fax: (+5521) 560-8028
} 


\section{MATERIALS AND METHODS}

\section{Standard strains}

The strains used as standards were antibiotic-susceptible bacteria obtained from American Type Culture Collection (ATCC; Rockville, MD, USA): Staphylococcus aureus (ATCC 6538), Salmonella cholerae suis (ATCC 10708) and Pseudomonas aeruginosa (ATCC 15442).

\section{Hospital isolates}

Twenty-seven Gram-positive and Gram-negative bacteria isolates were obtained during routine clinical investigation in Rio de Janeiro hospitals, Brazil, as follows: a) antibioticresistant isolates: methicillin-resistant Staphylococcus aureus - MRSA (5 strains from blood, surgical wound, nare, tracheostomy site and peritoneal fluid); S. epidermidis (2 strains), S. haemolyticus, Enterococcus, Serratia marcescens, Enterobacter cloacae, Escherichia coli (4 strains), Klebsiella pneumoniae (2 strains) and Proteus mirabilis (1 strain), all isolated from surgical site infections. Three Pseudomonas aeruginosa strains used in this study were isolated from surgical wounds and urinary infections; b) antibiotic-susceptible isolates: S. aureus, S. epidermidis, Enterococcus, E. cloacae, E. coli and $P$. mirabilis strains isolated from surgical site infections.

\section{Antibiotics susceptibility testing}

The susceptibility of the isolates to antibiotics was determined by the Kirby-Bauer method. A sterile swab was dipped in an bacteria suspension (McFarland standard 0.5) and placed onto Müeller Hinton Agar (Oxoide, Basingstoke, England). Antibiotic disks (CECON, São Paulo, Brazil) were applied using a sterile forceps. Agar plates were incubated at $35^{\circ} \mathrm{C}$ for $18 \mathrm{~h}$. The zone of inhibition was documented in millimeters. The susceptibility breakpoints were available using the criteria published by the National Committee for Clinical Laboratory Standards (NCCLS, 16). The following antibiotics recommended by the NCCLS for testing against Gram-positive strains were used: ampicillin - AP $(10 \mu \mathrm{g})$, penicillin G - PN (10 UI), oxacillin - OX (1 $\mu \mathrm{g})$, cephalotin - CF $(30 \mu \mathrm{g})$, cefoxitin - CFO $(30 \mu \mathrm{g})$, ceftazidime - CAZ $(30 \mu \mathrm{g})$, ceftriaxone - CRO $(30 \mu \mathrm{g})$, imipenem - IPM $(10 \mu \mathrm{g})$, vancomycin - VC $(30 \mu \mathrm{g})$, chloramphenicol - CO $(30 \mu \mathrm{g})$, erythromycin - EI $(15 \mu \mathrm{g})$, gentamicin - GN $(10 \mu \mathrm{g})$, amikacin - AM (30 $\mu \mathrm{g})$, tobramycin - TB $(10 \mu \mathrm{g})$, rifampicin - RF $(5 \mu \mathrm{g})$, trimethoprimsulphamethoxazole - SFT $(25 \mu \mathrm{g})$, tetracycline - TT $(30 \mu \mathrm{g})$ and ciprofloxacin - CIP $(5 \mu \mathrm{g})$. The Gram-negative strains were tested for: imipenem - IPM $(10 \mu \mathrm{g})$, ampicillin - AP $(10 \mu \mathrm{g})$, carbenicillin - CR $(100 \mu \mathrm{g})$, ciprofloxacin - CIP $(5 \mu \mathrm{g})$, clindamycin - CL $(2 \mu \mathrm{g})$, amikacin - AM $(30 \mu \mathrm{g})$, tetracycline - TT $(30 \mu \mathrm{g})$, cephalotin - CF $(30 \mu \mathrm{g})$, trimethoprimsulphamethoxazole - SFT (25 $\mu \mathrm{g})$, chloramphenicol - CO $(30 \mu \mathrm{g})$, gentamicin GN $(10 \mu \mathrm{g})$ and kanamycin - KN $(30 \mu \mathrm{g})$.
The antibiotic disks used for P.aeruginosa strains also included tobramycin - TB $(10 \mu \mathrm{g})$, norfloxacin - NOR $(10 \mu \mathrm{g})$, ofloxacin - OFX $(5 \mu \mathrm{g})$, aztreonan - $(30 \mu \mathrm{g})$, carbenicillin - CR $(100 \mu \mathrm{g})$, cephotaxime - CFO $(30 \mu \mathrm{g})$; and ceftazidime - CAZ $(30 \mu \mathrm{g})$.

\section{Disinfectants susceptibility testing}

Disinfectants: The following disinfectants commonly used in hospitals were selected and the use-dilution was performed in agreement with Ceras Johnson Ltda manufacturers' recommendations: sodium hypochlorite (commercial name: Virex), 2\%, (the use-dilution was 1:2 in sterile distilled water;); quaternary ammonium compound (commercial name: Duo-cide) (alkyl dimethyl ammonium chlorides, 9.5\%, 1:100 use-dilution in sterile distilled water); association quaternary ammonium compounds (alkyl dimethyl-benzyl ammonium chlorides, $0.6 \%$, alkyl ethyl-benzyl ammonium chlorides, $0.6 \%$ ), formaldehyde, $1.08 \%$ and ethyl alcohol, $43.93 \%$ (non use-dilution), commercial name: Germkil; glutaraldehyde (commercial name: Glutacide), $2.5 \%$ (non use-dilution); phenolics compounds (commercial name: Germpol) (o-benzyl-p-chlorophenol, 14.75\%, ophenylphenol, $2.4 \%$, and p-tertiary-buthylphenol, $1.9 \%$; the usedilution was 1:100 in sterile distilled water).

Methodology: The susceptibility of the hospital isolates to the disinfectants was determined by the technique of usedilution, according to the Association of Official Analytical Chemists International (4). Briefly, stainless steel ring carriers (penicylinders) were inoculated by soaking for 15 minutes in a 48-hour AOAC Disinfectant Test Broth (Difco) of test bacteria in the presence of an organic load (5\% horse serum, v/v). The carriers were removed with a hooked inoculating needle and allowed to dry for 40 minutes at $37^{\circ} \mathrm{C}$. After drying, the inoculated carriers were placed individually into the disinfectant solution and exposed for 10 minutes and then, were removed carefully and placed into tubes containing $10 \mathrm{ml}$ of Letheen neutralizing broth (Difco). The tubes were incubated for 48 hours and then examined for turbidity. Each carrier was inoculated with $10^{6}$ to $10^{7}$ bacteria determined by colonies counting on Trypticase Soy Agar (Difco) by pour plate method after salt bed dilutions obtained from one contaminated carrier. Sixty carriers were used for standard strain experiments, whereas twenty carriers were tested for hospital isolates. Each experimental run contained a "growth" control consisting of an inoculated carrier placed in sterile neutralizing broth. The standard strains were considered disinfectant-resistant when bacterial growth was observed in at least two tubes per 60 tubes tested (4). In relation to clinical strains the growth in at least one tube per 20 tubes tested was deemed as a disinfectantresistant strain.

\section{Statistical tests}

All comparisons were performed using Yates' chi-square tests. 


\section{RESULTS}

A wide divergence in the response to disinfectants and antibiotic agents was observed among the strains. The effect of disinfectants against the organisms is summarized in Tables 1, 2 and 3. Sodium hypochlorite, glutaraldehyde and the association quaternary ammonium compounds (QACs)formaldehyde-ethyl alcohol disinfectants were effective against the standard strains and all hospital isolates. The QAC and phenols did not demonstrate bactericidal activity against the standard strains (Table 1), except when the action of phenolics against Salmonella cholerae suis was analyzed (growth in one tube).

The results of the experiments using disinfectants against the susceptible hospital strains (Table 2) demonstrated that $P$. mirabilis and S. epidermidis strains were resistant to the QAC and phenolic compounds, respectively.
Among twenty-one pathogens resistant to antibiotics (Table 3), 11 strains (52\%) were resistant to the QAC (three MRSA strains, S. haemolyticus, E. cloacae, E. coli, two K. pneumoniae strains, $P$. mirabilis and two P. aeruginosa strains). Eight isolates (38\%) (one MRSA strain, two $S$.epidermidis strains, E. cloacae, P. mirabilis, S. marcescens and two P. aeruginosa strains) demonstrated resistance to the phenolic compounds. Three Gram negative strains (E. cloacae, P. mirabilis and $P$. aeruginosa) were resistant to both disinfectants.

Among twenty-one antibiotic-resistant strains available, 11 showed resistance to more than ten antibiotics, while the majority was resistant to at least three antibiotics. All antibioticresistant staphylococci were methicillin-resistant and susceptible only to vancomycin, tetracycline, ciprofloxacin, amikacin and rifampicin. The Enterococcus strain presented high-level- resistance (HLR) to gentamycin. The Enterobacteriaceae strains were resistant mainly to ampicillin,

Table 1 - Evaluation of bactericidal activity of hospital disinfectants against standards strains

\begin{tabular}{lccccc}
\hline & \multicolumn{4}{c}{ Disinfectants (use-dilution) } \\
\cline { 2 - 5 } \multicolumn{1}{c}{ Standard strains } & $\begin{array}{c}\text { Sodium } \\
\text { hypochlorite }\end{array}$ & Glutaraldehyde & $\begin{array}{c}\text { Formaldehyde- } \\
\text { QAC*-EA }^{\dagger} \\
\text { association }\end{array}$ & QAC & Synthetic phenols \\
\cline { 2 - 5 } & $(1: 2)$ & (non diluted) & (non diluted) & $(1: 100)$ & $(1: 100)$ \\
\hline S. aureus ATCC 6538 & $0 / 60^{\ddagger}$ & $0 / 60$ & $0 / 60$ & $7 / 60$ & $2 / 60$ \\
S. choleraesuis ATCC 10708 & $0 / 60$ & $0 / 60$ & $0 / 60$ & $4 / 60$ & $1 / 60$ \\
Ps. aeruginosa ATCC 15442 & $0 / 60$ & $0 / 60$ & $0 / 60$ & $5 / 60$ & $7 / 60$ \\
\hline
\end{tabular}

*QAC: quaternary ammonium compound

${ }^{\dagger}$ EA: ethyl alcohol

Number of positive tubes per 60 tubes containing the test microorganism.

Table 2: Evaluation of bactericidal activity of disinfectants against antibiotic-susceptible hospital strains

\begin{tabular}{lccccc}
\hline & \multicolumn{5}{c}{ Disinfectants (use-dilution) } \\
\cline { 2 - 5 } \multicolumn{1}{c}{ Clinical strains } & $\begin{array}{c}\text { Sodium } \\
\text { hypochlorite }\end{array}$ & Glutaraldehyde & $\begin{array}{c}\text { Formaldehyde- } \\
\text { QAC*EA }^{*} \\
\text { association }\end{array}$ & QAC & Synthetic phenols \\
\cline { 2 - 5 } & $(1: 2)$ & (non diluted) & (non diluted) & $(1: 100)$ & $(1: 100)$ \\
\hline Staphylococcus aureus & $0 / 20^{\ddagger}$ & $0 / 20$ & $0 / 20$ & $0 / 20$ & $0 / 20$ \\
Staphylococcus epidermidis & $0 / 20$ & $0 / 20$ & $0 / 20$ & $0 / 20$ & $1 / 20$ \\
Enterococcus & $0 / 20$ & $0 / 20$ & $0 / 20$ & $0 / 20$ & $0 / 20$ \\
Enterobacter cloacae & $0 / 20$ & $0 / 20$ & $0 / 20$ & $0 / 20$ & $0 / 20$ \\
Proteus mirabilis & $0 / 20$ & $0 / 20$ & $0 / 20$ & $1 / 20$ & $0 / 20$ \\
Escherichia coli & $0 / 20$ & $0 / 20$ & $0 / 20$ & $0 / 20$ & $0 / 20$ \\
\hline
\end{tabular}

*QAC: quaternary ammonium compound

"EA: ethyl alcohol

*Number of positive tubes per 20 tubes containing the test microorganism. 
cephalothin, tetracycline and chloramphenicol, while the $P$. aeruginosa strains showed variable susceptibility to imipenen, quinolones, aztreonan and ceftazidime.

No significant statistical differences $(p>0.05)$ were verified between QAC and phenol germicides when tested against standard strains or hospital isolates. Comparing the antibioticsusceptible and the antibiotic-resistant isolates, QAC and phenols had similar efficacy to both types $(\mathrm{p}>0.05)$.

\section{DISCUSSION}

The goal of disinfection is to reduce the risk of endemic and epidemic nosocomial infections in patients. A great number of disinfectants are used in the healthcare setting, including glutaraldehyde, formaldehyde and chloride-releasing agents compounds. These agents are considered sporicidal chemicals when used in appropriated concentrations and are recommended for patient-care items and instruments (20). In this study, we verified that these disinfectants were effective when tested against standard and clinical bacterial strains.

Although bacterial resistance to antibiotics has been extensively studied, only a few reports are available on disinfectant action against microorganisms. Very few studies demonstrate the correlation between these two types of antimicrobials. Anderson et al. (3) and Rutala et al. (21), testing hospital isolates, did not find evident correlation between susceptibility to antibiotics and to disinfectants for any clinical strain. However, MRSA have been considered more resistant

Table 3: Evaluation of bactericidal activity of disinfectants against antibiotic-resistant hospital strains

\begin{tabular}{|c|c|c|c|c|c|}
\hline \multirow{3}{*}{ Clinical strains } & \multicolumn{5}{|c|}{ Disinfectants (use-dilution) } \\
\hline & $\begin{array}{c}\text { Sodium } \\
\text { hypochlorite }\end{array}$ & Glutaraldehyde & $\begin{array}{c}\text { Formaldehyde- } \\
\text { QAC }^{*} \text {-EA } \\
\text { association }\end{array}$ & QAC & Synthetic phenols \\
\hline & $(1: 2)$ & (non diluted) & (non diluted) & $(1: 100)$ & $(1: 100)$ \\
\hline Staphylococcus aureus & $0 / 20^{\ddagger}$ & $0 / 20$ & $0 / 20$ & $1 / 20$ & $0 / 20$ \\
\hline S. aureus & $0 / 20$ & $0 / 20$ & $0 / 20$ & $0 / 20$ & $1 / 20$ \\
\hline S. aureus & $0 / 20$ & $0 / 20$ & $0 / 20$ & $1 / 20$ & $0 / 20$ \\
\hline S. aureus & $0 / 20$ & $0 / 20$ & $0 / 20$ & $1 / 20$ & $0 / 20$ \\
\hline S. aureus & $0 / 20$ & $0 / 20$ & $0 / 20$ & $0 / 20$ & $0 / 20$ \\
\hline Staphylococcus epidermidis & $0 / 20$ & $0 / 20$ & $0 / 20$ & $0 / 20$ & $1 / 20$ \\
\hline S. epidermidis & $0 / 20$ & $0 / 20$ & $0 / 20$ & $0 / 20$ & $2 / 20$ \\
\hline S. haemolyticus & $0 / 20$ & $0 / 20$ & $0 / 20$ & $2 / 20$ & $0 / 20$ \\
\hline Enterococcus & $0 / 20$ & $0 / 20$ & $0 / 20$ & $0 / 20$ & $0 / 20$ \\
\hline Escherichia coli & $0 / 20$ & $0 / 20$ & $0 / 20$ & $0 / 20$ & $0 / 20$ \\
\hline Escherichia coli & $0 / 20$ & $0 / 20$ & $0 / 20$ & $0 / 20$ & $0 / 20$ \\
\hline Escherichia coli & $0 / 20$ & $0 / 20$ & $0 / 20$ & $0 / 20$ & $0 / 20$ \\
\hline Escherichia coli & $0 / 20$ & $0 / 20$ & $0 / 20$ & $1 / 20$ & $0 / 20$ \\
\hline Enterobacter cloacae & $0 / 20$ & $0 / 20$ & $0 / 20$ & $1 / 20$ & $1 / 20$ \\
\hline Klebsiella pneumoniae & $0 / 20$ & $0 / 20$ & $0 / 20$ & $1 / 20$ & $0 / 20$ \\
\hline K. pneumoniae & $0 / 20$ & $0 / 20$ & $0 / 20$ & $1 / 20$ & $0 / 20$ \\
\hline Proteus mirabilis & $0 / 20$ & $0 / 20$ & $0 / 20$ & $2 / 20$ & $1 / 20$ \\
\hline Serratia marcescens & $0 / 20$ & $0 / 20$ & $0 / 20$ & $0 / 20$ & $1 / 20$ \\
\hline Pseudomonas aeruginosa & $0 / 20$ & $0 / 20$ & $0 / 20$ & $0 / 20$ & $1 / 20$ \\
\hline Ps. aeruginosa & $0 / 20$ & $0 / 20$ & $0 / 20$ & $3 / 20$ & $3 / 20$ \\
\hline Ps. aeruginosa & $0 / 20$ & $0 / 20$ & $0 / 20$ & $1 / 20$ & $0 / 20$ \\
\hline
\end{tabular}

*QAC: quaternary ammonium compound

EA: ethyl alcohol

*Number of positive tubes per 20 tubes containing the test microorganism. 
to quaternary ammonium compounds than methicillinsusceptible $S$. aureus (MSSA) strains $(1,6)$ and linkage between antibiotic and chlorine resistance has been also demonstrated among sewage-related bacteria (14). In this study, we did not observe any relationship between susceptibility to antibiotics and disinfectants ( $p>0.05)$, despite of the high number of strains which were resistant to antibiotics (21 strains) in relation to the number of antibiotic-sensitive strains ( 6 strains) when tested against disinfectants.

Some studies have evidenced the involvement of plasmids in the resistance to some disinfectants, such as heavy metals (11) and formaldehyde (27). An existing cross-resistance between QACs and aminoglycosides, codified by plasmids, has been reported in MRSA strains, leading to the suggestion that the extensive use of cationic agents in the hospital environment can be a factor responsible for the emergence of resistant strains to antibiotic agents $(6,25)$. Recently, resistance to cationic agents and to antibiotics mediated by the same plasmids has been also observed in coagulase-negative staphylococci (CoNS), microorganisms associated with infections in implanted foreign bodies (12). Tennent and coleagues (24) suggested that staphylococci evade destruction because the protein specified by the qac A determinant, located in a plasmid locus, is a cytoplasmic membrane-associated protein involved in an efflux system that actively reduces intracellular accumulation of the QAC. In this report, the analysis of staphylococci, as a group, demonstrated that four methicillin-resistant staphylococci strains (three $S$. aureus strains and one $S$. haemolyticus strain), resistant to aminoglycoside, presented resistance mainly to the QAC (4/8 strains; Table 3), while all antibiotic-sensitive strains were sensitive to the QAC (Table 2). MRSA and MSSA strains assessed in this report showed similar responses to phenolic compounds, as observed previously (1).

The high colonization rate of the inpatients with Enterococcus strains resistant to several antibiotic agents, especially ampicillin and aminoglycosides, represents a challenge to the therapy of these nosocomial infections. Recently, vancomycin-resistant enterococci (VRE) have also emerged as serious nosocomial pathogens (7). However, some reports have shown that the vancomycin-resistant and susceptible enterococci isolated from various clinical sources and inanimate surfaces, when challenged in disinfectant tests, demonstrated similar survival $(3,21,22)$. In our study, only two Enterococcus, antibiotic-resistant and -sensitive strains, isolated from surgical site infections were analyzed and showed susceptibility to all disinfectants used (Tables 2 and 3). A greater number of isolates should be investigated to allow a better comparison.

Gram-negative bacteria are generally less susceptible to biocides than Gram-positive species. Such resistance is likely to be intrinsic rather than plasmid-mediated, due to outer membrane that acts as a protective barrier (19). Hospital isolates of Gram-negative bacteria belonging to the Enterobacteriaceae family, such as Klebsiella, Enterobacter, Serratia and Proteus, have shown resistance to disinfectants, mainly quaternary ammonium compounds and phenols $(10,18)$. Hammond and coworkers (10) showed that the majority of antibiotic-sensitive Escherichia coli strains were inhibited by QACs and that strains of Klebsiella, Serratia and Proteus were uniformly more resistant to the quaternaries than E. coli. However, most of these organisms were also susceptible to the majority of antibiotics. Stickler and Thomas (23) demonstrated that $15 \%$ of strains of Gram-negative bacteria isolated from urinary tract infection were more resistant to QACs, as well as, to antibiotics. Navajas et al (16) showed that the phenol compounds were less active than QACs when 70 hospital strains of Gramnegative bacteria were tested. In the present study, the antibiotic-resistant hospital strains of $P$. mirabilis and $E$. cloacae were resistant to the QAC and synthetic phenols (Table 3 ), whereas the $K$. pneumoniae strains were only resistant to the QAC. In spite of the lack of significant statistical differences ( $p>0.05$ ) between antibiotic-resistant and -sensitive isolates when tested against disinfectants, E. cloacae and $P$. mirabilis strains susceptible to antibiotics were more sensitive to disinfectants (Table 2) than Gram-negative resistant ones (Table 3 ). We also found that E. coli strains were more susceptible to disinfectants than other Enterobacteriaceae tested, as demonstrated by Hammond et al. (10).

Due to the capacity of surviving in unfavorable environmental conditions and to the high resistance to antibiotic agents, antiseptics and disinfectants, $P$. aeruginosa continues to be an important pathogen in hospital acquired infections, mainly respiratory and urinary infections. The transmission of this bacterium is almost always related to contamination of medical-surgical instruments and respiratory apparatus (8). Vess et al. (26) demonstrated that Pseudomonas spp survive during long periods on the surfaces of polyvinyl chloride (PVC) pipes, showing tolerance to the treatment with different disinfectants (synthetic phenols, QACs, formaldehyde and chlorine), and could become a potent reservoir of microbial contamination. Fernandéz-Astorga et al (9) have reported that the high resistance of Pseudomonas spp to cationics agents seems to be associated with the chemical composition of the external membrane. Our study demonstrated that $P$. aeruginosa strains were resistant to the antibiotic agents, as well as to the QAC and phenols. Nevertheless, the only strain susceptible to the QAC showed also more susceptibility to antibiotics used in the therapeutic of infectious diseases caused by this microorganism, such as cefotaxime, aztreonan, ceftazidime and quinolones.

The more appropriate disinfectants for hospital disinfection were aldehydes and hypochlorite. In relation to phenols and QACs, sometimes used in routine surface disinfection (contaminated hospital rooms) in Brazilian hospitals, they 
should be used in higher concentrations in order to achieve the requisites mentioned by Rutala et al. (21). However, disinfectant products should be selected more appropriately, as part of infection control practices, based on particular circunstances. For example, certain active agents, like QACs, are more effective against gram-positive than gram-negative bacteria (13).

Studies to determine the possible relationship between antibiotic resistance and disinfectant resistance of clinical isolates are rare. The precise role of plasmids in disinfectant resistance and whether disinfectants can select for antibiotic resistance are unknown. With growing concerns about the development of biocide resistance and cross-resistance with antibiotics, it is clear that clinical isolates should be under continual surveillance and possible mechanisms associated with disinfectant-resistance should be more investigated.

\section{ACKNOWLEDGMENTS}

This work was supported by FAPERJ, FUJB, CNPq and PRONEX, Rio de Janeiro, RJ, Brazil.

\section{RESUMO}

\section{Análise comparativa da atividade de antibióticos e desinfetantes em amostras hospitalares brasileiras}

As infecções nosocomiais têm se tornado uma importante causa de morbidade e mortalidade em todo o mundo. Práticas adequadas de higiene e desinfecção ambiental são fundamentais para o controle destas infecções. O objetivo deste trabalho foi avaliar a atividade bactericida de alguns desinfetantes em amostras hospitalares resistentes e sensíveis à antibióticos. A susceptibilidade aos desinfetantes e antibióticos de 27 amostras clínicas foi determinada pelo Método de Diluição de Uso (AOAC) e pelo Método de Kirby-Bauer, respectivamente. Os resultados mostraram que todas as amostras testadas foram susceptíveis ao hipoclorito de sódio, ao glutaraldeído e à associação de quaternário de amônio-formaldeído-álcool etílico. Contudo, a susceptibilidade das amostras ao fenol e ao quaternário de amônio se mostrou variável. Entre 21 amostras multirresistentes à antibióticos (Staphylococcus resistente à meticilina, Enterococcus spp, Pseudomonas aeruginosa, Klebsiella pneumoniae, Proteus mirabilis, Enterobacter cloacae, Serratia marcescens e Escherichia coli) onze (52\%) e oito $(38 \%)$ foram resistentes ao composto quaternário de amônio e aos fenóis, respectivamente. Dentre as 6 amostras que demonstraram susceptibilidade aos antibióticos (estafilococos, Enterococcus spp, P. mirabilis, E. cloacae e E. coli), duas amostras (33\%) mostraram resistência a estes desinfetantes. Os resultados observados neste estudo mostraram que não houve correlação entre susceptibiliadde à antibióticos e susceptibilidade à desinfetantes quando foram analisadas amostras clínicas hospitalares.

Palavras-chave: atividade desinfetante, atividade de antibióticos, amostras hospitalares

\section{REFERENCES}

1. Al Masaudi, S.B., Day, M.J.; Russell, A.D. Sensitivity of methicillin-resistant Staphylococcus aureus strains to some antibiotics, antiseptics and disinfectants. J. Appl. Bacteriol. 65: 329-337, 1988

2. Amyes G.B.; Gemmell C.G. Antibiotic resistance. J. Med.Microbiol. 46: 436470, 1997.

3. Anderson, R.L; Carr, J.H.; Bond, W.W.; Favero, M.S. Susceptibility of vancomycin-resistant enterococci to environmental disinfectants. Infect.Control Hosp. Epidemiol. 18: 195-199, 1997

4. Association of Official Analytical Chemists International (AOAC). Off. Meth. Analysis. 15 th Ed. Arlington, 1990, 1117p.

5. Ayliffe, G.A.J.; Collins, B.J. Problems of disinfection in hospitals. In: Russell, A.D.; Hugo, W.B.; Ayliffe, G.A.J.(eds). Principles and Practice of Disinfection, Preservation and Sterilization. Blackwell Scientific Publication, Oxford, 1992, p. 292-309.

6. Brumfitt, W.; Dixson, S.; Hamilton Miller, J.M.T. Resistance to antiseptics in methicillin and gentamicin resistant Staphylococcus aureus. Lancet $\mathrm{i}$ 1442-1443, 1985.

7. Centers for Disease Control and Prevention (CDC). Nosocomial enterococci resistant to vancomycin- United States, 1989-1993. MMWR 42: 597-599, 1993.

8. Climo, M.W.; Pastor, A.; Wong, E.S. An outbreak of Pseudomonas aeruginosa related to contaminated urodynamic equipment. Infect. Control Hosp. Epidemiol. 18: 509-510, 1997.

9. Fernández-Astorga, A.; Hijarrubia, M.J.; Hernández, M.; Arana, I.; Suñen, E. Disinfectant tolerance and antibiotic resistance in psychrotrophic Gramnegative bacteria isolated from vegetables. Lett. Appl. Microbiol. 20: 308$311,1995$.

10. Hammond, S.A.; Morgan, J.R.; Russell, A.D. Comparative susceptibility of hospital isolates of Gram-negative bacteria to antiseptics and disinfectants. $J$. Hosp. Infect. 9: 255-264, 1987.

11. Khor, S.Y.; Jegathesan, M. Heavy metal and disinfectant resistance in clinical isolates of Gram-negative rods. South East Asian J. Trop. Med. Public Health 14: 199-203, 1983.

12. Leelaporn, A.; Paulsen, I.T.; Tennent, J.M.; Littlejohnn, T.G.; Skurray, R. A. Multidrug resistance to antiseptics and disinfectants in coagulase-negative staphylococci. J. Med. Microbiol. 40: 214-220, 1994.

13. McDonnell, G.; Russell, D. Antiseptics and disinfectants: activity, action, and resistance. Clin. Microbiol. Rev.,12: 147-179, 1999.

14. Murray, G.E.; Tobin, R.S.; Kushner, D.J. Effect of chlorination on antibiotic resistance profiles of sewage-related bacteria. App. Environ. Microbiol. 48: 73-77, 1984.

15. National Committee for Clinical Laboratory Standards (NCCLS). Performance standards for antimicrobial disk susceptibility tests. NCCLS M2-A5. 5 th Ed. Villanova, 1993.

16. Navajas, R.F.C.; Diaz, R.M.; Del Castillo, A.S.; Marín, M.A.I. Concentraciones mínimas inhibitorias y bactericidas de algunos antisépticos y desinfectantes frente a cepas de origen hospitalario. Rev. Latino Am. Microbiol. 34: 1-6, 1992

17. Pannutti, C.S.; Grinbaum, R.S. An Overview of nosocomial infection control in Brazil. Infect. Control Hosp. Epidemiol. 16: 170-174, 1995.

18. Russell, A.D.; Hammond, S.A.; Morgan, J.R. Bacterial resistance to antiseptics and disinfectants. J. Hosp. Infect. 7: 213-225, 1986.

19. Russell, A. D. Plasmids and bacterial resistance to biocides: a review. J. App. Microbiol. 82:. 155-165, 1997.

20. Rutala, W.A. Disinfection, sterilization and waste disposal. In: Wenzel, R.P (ed). Prevention and Control of Nosocomial Infections. Williams \& Wilkins, Baltimore, 1997, p.539-593.

21. Rutala, W.A.; Stiegel, M.M.; Sarubbi, F.A.;Weber, D.J. Susceptibility of antibiotic-susceptible and antibiotic-resistant hospital bacteria to disinfectants. Infect. Control Hosp. Epidemiol. 18: 417-421, 1997. 
22. Saurina, G.; Landman, D.; Quale, J.M. Activity of disinfectants against vancomycin-resistant Enterococcus faecium. Infec. Control Hosp. Epidemiol. 18: 345-347, 1997.

23. Stickler, D.J.; Thomas, B. Antiseptic and antibiotic resistance in Gramnegative bacteria causing urinary tract infection. J. Clin. Pathol. 33: 288$296,1980$.

24. Tennent J.M.; Lyon B.R.; Midgley M.; Jones I.G.; Purewal, A.S.; Skurray, R.A. Physical and biochemical characterization of the qacA gene encoding antiseptic and disinfectant resistance in Staphylococcus aureus. J. Gen. Microbiol. 135: 1-10, 1989.
25. Towsend, D.E.; Ashdow, N.; Greed, L.C.; Grubb, W.B. Transposition of gentamicin resistance to staphylococcal plasmids encoding resistance to cationic agents. J. Antimicrob. Chemother. 14: 115-124, 1984.

26. Vess, R.W.; Anderson, R.L.; Carr, J.H.; Bond, W.W.; Favero, M.S. The colonization of solid PVC surfaces the acquisition of resistance to germicides by water microorganisms. J. App. Bacteriol. 74: 215-221, 1993.

27. Wollmann, A.; Kaulfers, P.M. Formaldehyde-resistance in Enterobacteriaceae and Pseudomonas aeruginosa: identification of resistance genes by DNA-hybridization. Zbl. Bakt. Mikrobiol. Hyg. 191: 449456, 1991. 